\title{
Analysis on the Development History and Trend of "Three System Reforms" of State-Owned Enterprises
}

\author{
Sun Lichun ${ }^{1, a^{*}}$, Qi Jinchang ${ }^{2, b}$, Zhang Hualei ${ }^{3, c}$ \\ ${ }^{1}$ State Grid Energy Research Institude CO. LTD, Changping District, Beijing, P.R. China \\ ${ }^{2}$ State Grid Corporation of China, Xicheng District, Beijing, P.R. China \\ ${ }^{3}$ State Grid Energy Research Institude CO. LTD, Changping District, Beijing, P.R. China \\ $a^{*}$ sunlichun@sgeri.sgcc.com.cn \\ bjinchang-qi@sgcc.com.cn \\ ${ }^{c}$ zhanghualei@sgeri.sgcc.com.cn
}

\begin{abstract}
The "three system reforms" of state-owned enterprises are aimed at the reform of state-owned enterprises' labor, personnel, and distribution systems. The labor system is mainly reflected in the employment methods and labor relations. The personnel system mainly refers to the management of leading cadres, and the distribution system includes the management of total state-owned enterprise wages, Internal salary distribution mechanism, etc. Why did the three system reforms last for decades? What is the difference between the current reform and historical reform? In response to the above questions, this article sorts out the development history of the three system reforms, summarizes the reform priorities and related effects at different stages, and makes preliminary judgments on the deepening development trend of the three system reforms under new situations.
\end{abstract}

Keywords: Three system reforms, development course, achievements of reform, reform tendency

\section{国有企业 “三项制度改革” 发展历程及趋势分析}

$$
\text { 孙李淳 }{ }^{1,} \mathrm{a}^{*} \text { 齐金昌 }^{2,} \text { b 张华䂞 }{ }^{3, c}
$$

\footnotetext{
${ }^{1}$ 国网能源研究院有限公司, 昌平, 北京, 中国

2 国家电网有限公司, 西城, 北京, 中国

3 国网能源研究院有限公司, 昌平, 北京, 中国

$a^{*}$ sunlichun@sgeri.sgcc.com.cn

bjinchang-qi@sgcc.com.cn

czhanghualei@sgeri.sgcc.com.cn
}

\section{摘要}

国有企业 “三项制度改革” 是针对国有企业劳动、人事、分配制度的改革, 其中劳动制度主要体现在用工方式、 劳动关系等方面, 人事制度主要指领导干部管理, 分配制度包括国企工资总额管理、内部薪酬分配机制等内容。 为何三项制度改革持续数十年？现阶段改革与历史上有何差异？为回应上述疑问，本文对三项制度改革的发 展历程进行了梳理，总结不同阶段的改革侧重点及相关成效，并对新形势下三项制度改革深化发展趋势做出初 步研判。

关键词: 三项制度改革，发展历程，改革成效，改革趋势

1. 前言

自改革开放初期以来，国有企业三项制度改革攻
坚工作伴随着我国市场经济体制的逐步发展而持续 推进。进入二十一世纪后, 加入 WT0 加快了我国企业 与现代管理科学接轨进程, 推进三项制度改革对于拉 
近国有企业与成熟市场中的现代企业之间的管理差 距, 具有重要意义。

\section{2. 发展阶段划分}

结合经济体制改革、国资国企改革历程，国有企 业三项制度改革可划分为四个阶段, 综合比较见表 1 。

\section{1. 起步探索阶段（1978-1992 年）}

在放权让利、政企分开的国企改革大背景下，国 有企业 “三项制度”也进行了配套改革。随着一系列 政策发布实施，国有企业在 “劳动用工、人事管理、 工资奖金分配” 方面的自主权逐步落实, “干部能上 能下、职工能进能出、工资能升能降” 的改革目标被 明确提出。重点政策包括: 1981 年 11 月, 国务院批 转《关于实行工业生产经济责任制若干问题的暂行规 定》; 《国务院关于进一步扩大国营工业企业自主权 的暂行规定》（国发(1984)67号）; 《国务院关于 发布改革劳动制度四个规定的通知》（国发(1986) 77 号); 《关于深化企业劳动人事、工资分配、社会 保险制度改革的意见》（劳政字（1992）2号）；1992 年 7 月, 《全民所有制工业企业转换经营机制条例》 （国务院第 103 号令）。

从这一阶段的改革举措及改革成效来看, “三项 制度改革” 始于下放干部人事管理权、打破干部 “终 身制”、打破 “干部”与 “工人” 的身份界限 (从工 人中聘用管理人员），企业自主录用职工与打破 “毕 业分配制度” 同步推进，提高了劳动要素配置效率、 初步释放了人才活力。 80 年代中期开始对国有企业 实行 “工效挂钩” , 试行劳动合同制, 实行岗位结构 工资制等, 初步打破了计划经济体制及“八级工资制” 长期实施错位带来的工资无法提升、大锅饭盛行的局 面。因社会保障制度尚不完善, 1992 年针对国企 “铁 饭碗” (用工制度)、“铁工资” (工资制度)、“铁 交椅” (干部制度) 的 “破三铁” 运动轰轰烈烈之后 戛然而止, 改革策略重回放权主题, 劳动力市场建设 工作开始推进、社会保障制度开始建立完善。

\section{2. 系统突破阶段（1993-2002 年）}

随着我国社会主义市场经济的基本确立, 国有企 业步入现代化建设阶段, 为进一步释放国有企业活力, 三项制度改革的力度和广度显著提升。国有企业 “劳 动、人事、分配” 三项制度改革要求得以明确, 改革 工作全面部署推进。90 年代中期开始, 深化企业劳动 人事、工资分配、社会保险制度综合配套改革，推进 劳动合同制, 逐步实行以岗位技能工资为主要内容的 基本工资制度, 逐步扩大社会保险范围、提高社会化 程度；1998-2000 年在国企改革三年攻坚战中明确并 开始全面改革国企三项制度。 ${ }^{[2]}$ 重点政策包括《国有 大中型企业建立现代企业制度和加强管理的基本规 范（试行）》(国办发〔2000)64号); 《关于深化国 有企业内部人事、劳动、分配制度改革的意见》（国
经贸企改〔2001〕230 号）。

总得来说, 改革理念及改革工具的现代化水平进 一步提升。改革对象由 “干部” 变为 “管理人员”, 意味着 “身份” 管理逐步被突破, 岗位管理机制得以 落实; 由 “工资” 变为 “收入”，代表着国有企业的 激励工具更为丰富, 短期激励之外, 中长期激励工具 开始试点实施; “竞聘上岗”、“择优录用”、“有 效激励”等现代企业管理理念、制度得到进一步强调。 劳动力市场初现维形, 配套社会保障制度体系进一步 完善, 为劳动要素的市场化流动配置奠定了基础。

\section{3. 配套机制完善阶段（2003-2013 年）}

随着国务院国资委的成立，国有企业特别是中央 企业三项制度改革持续推进，与现代企业制度的建立 完善相辅相成, 在如何管理国有企业领导人员, 如何 调节国家、企业、职工三者收入分配关系等方面做了 一些有益探索，配套机制得以初步建立。 ${ }^{[3]}$ 标志性事 件如 2010 年起改革原有工资总额决定方式（由工效 挂钩改为工资总额预算制）、完善央企负责人考核及 薪酬制度等, 在部分中央企业开展分红权激励试点。 重点政策包括《关于深化中央企业劳动用工和内部收 入分配制度改革的指导意见》（国资发分配〔2009) 299 号)； 《关于进一步加强中央企业全员业绩考核 工作的指导意见》（国资发综合〔2009〕300 号）。

总得来说，这一阶段国有企业 “三项制度”改革 与现代企业制度的建立完善相辅相成, 企业内部管理 机制的市场化变革拉开序幕, 岗位管理、绩效管理、 薪酬激励、福利保障等工作协同推进, 为完善市场化 用工机制、合理拉开收入差距、有效激励约束奠定了 坚实基础, 企业与员工共担风险、共同发展的理念和 机制初步形成、落地。

\section{4. 深化改革阶段 (2013 年至今)}

随着国资国企监管逐步由“管资产”向“管资本” 转变, 企业经营管理自主权进一步得以落实, 国有企 业 “三项制度” 改革的市场化导向愈发突出。《关于 进一步深化中央企业劳动用工和收入分配制度改革 的指导意见》（国资发分配〔2016)102 号）提出建 立与社会主义市场经济相适应、与企业功能定位相配 套的市场化劳动用工和收入分配管理体系, 实现企业 内部管理人员能上能下、员工能进能出、收入能增能 减, 增强中央企业活力和竞争力。

近年来, 针对不同类型企业的改革配套机制、针 对重点人群的激励约束机制等日趋完善。一方面, “三 项制度” 改革已进入全面创新、精益施策的新阶段, 随着监督约束机制日益完善、高质量发展目标更为明 确, 三项制度改革更加突出 “正向激励” 导向, 中长 期激励政策和工具更加完善, 人力资本要素价值得到 进一步凸显, 需要各类企业根据改革发展需要解决瓶 颈性问题、优化经营管理模式、创新管理机制设计。 
另一方面, 劳动用工机制、激励约束机制的进一步市

国有企业公司治理机制改革的迫切性越发凸显。

场化改革还需要体制变革作基础，国资授权经营体系、

表 1 国企三项制度改革各阶段综合比较

\begin{tabular}{|c|c|c|c|c|c|}
\hline \multirow{2}{*}{ 阶段 } & \multirow{2}{*}{ 改革重点 } & \multirow{2}{*}{ “六能” 目标 } & \multicolumn{3}{|c|}{ 主要政策部署及改革举措 } \\
\hline & & & 选聘及考核机制 & 分配机制 & 用工及退出机制 \\
\hline $\begin{array}{l}1978^{-} \\
1992 \text { 年 }\end{array}$ & $\begin{array}{l}\text { 落实企业在“劳 } \\
\text { 动用工、人事管 } \\
\text { 理、工资奖金分 } \\
\text { 配”方面的自主 } \\
\text { 权”。 }\end{array}$ & $\begin{array}{l}\text { 干 部 能上能 } \\
\text { 下、职工能进 } \\
\text { 能出、工资能 } \\
\text { 升能降。 }\end{array}$ & $\begin{array}{l}\checkmark \text { 可从工人中选聘 } \\
\text { 管理人员; 可自主 } \\
\text { 进行公开招工; } \\
\checkmark \text { 对管理人员和技 } \\
\text { 术人员可以实行 } \\
\text { 聘用制、考核制。 }\end{array}$ & $\begin{array}{l}\text { 实施 “功效挂钩”, } \\
\text { 可实行岗位结构工 } \\
\text { 资制。 }\end{array}$ & $\begin{array}{l}\text { 可自主决定用工 } \\
\text { 形式、可实行合同 } \\
\text { 化管理或全员劳 } \\
\text { 动合同制。 }\end{array}$ \\
\hline $\begin{array}{l}1993^{-} \\
2002 \text { 年 }\end{array}$ & $\begin{array}{l}\text { 深化企业劳动 } \\
\text { 人事、工资分 } \\
\text { 配、社会保险制 } \\
\text { 度综合配套改 } \\
\text { 革。 }\end{array}$ & $\begin{array}{l}\text { 职工能 进能 } \\
\text { 出、管理人员 } \\
\text { 能上能下、收 } \\
\text { 入能增能减。 }\end{array}$ & $\begin{array}{l}\checkmark \text { 推行全员竞争上 } \\
\text { 岗制度; } \\
\checkmark \text { 打破“干部”和“工 } \\
\text { 人” 的身份界限, } \\
\text { 推行各级管理人 } \\
\text { 员的公开竞聘及 } \\
\text { 任期制; } \\
\checkmark \text { 对员工进行岗位 } \\
\text { 动态考核。 }\end{array}$ & $\begin{array}{l}\checkmark \text { 建立以岗位工资 } \\
\text { 为主要形式的工 } \\
\text { 资制度; } \\
\checkmark \text { 对经营管理者可 } \\
\text { 试行年薪制、持有 } \\
\text { 股权、股票期权; } \\
\checkmark \text { 针对专业技术人 } \\
\text { 员、营销人员特点 } \\
\text { 完善激励分配制 } \\
\text { 度。 }\end{array}$ & $\begin{array}{c}\checkmark \text { 对劳动合同实 } \\
\text { 行动态管理, } \\
\text { 依据考核结果 } \\
\text { 实行内部淘汰 } \\
\text { 办法; } \\
\checkmark \text { 任期内不称职 } \\
\text { 的管理人员, } \\
\text { 可以通过企业 } \\
\text { 的规定程序予 } \\
\text { 以提前解聘。 }\end{array}$ \\
\hline $\begin{array}{l}2003^{-} \\
2013 \text { 年 }\end{array}$ & $\begin{array}{l}\text { 加强国有企业 } \\
\text { 领导人员管理, } \\
\text { 调节国家、企 } \\
\text { 业、职工三者收 } \\
\text { 入分配关系。 }\end{array}$ & $\begin{array}{l}\text { 管理者能上能 } \\
\text { 下、员工能进 } \\
\text { 能出、薪酬能 } \\
\text { 高能低。 }\end{array}$ & $\begin{array}{l}\text { 完善央企负责人考 } \\
\text { 核及薪酬制度。 }\end{array}$ & $\begin{array}{l}\checkmark \text { 由工效挂钩改为 } \\
\text { 工资总额预算制; } \\
\checkmark \text { 在部分中央企业 } \\
\text { 开展分红权激励 } \\
\text { 试点; } \\
\checkmark \text { 加强岗位分析评 } \\
\text { 价, 合理确定岗位 } \\
\text { 工资水平; } \\
\checkmark \text { 探索生产要素按 } \\
\text { 贡献参与分配方 } \\
\text { 式、加大对关键人 } \\
\text { 才的激励力度, 完 } \\
\text { 善职工新酬福利 } \\
\text { 体系。 }\end{array}$ & $\begin{array}{l}\checkmark \text { 要建立以合同 } \\
\text { 管理为核心、以 } \\
\text { 岗位管理为基 } \\
\text { 础的市场化用 } \\
\text { 工机制; } \\
\checkmark \text { 要建立健全人 } \\
\text { 员进出机制、促 } \\
\text { 进职工合理流 } \\
\text { 动。 }\end{array}$ \\
\hline $\begin{array}{l}2013 \text { 年 } \\
\text { 至今 }\end{array}$ & $\begin{array}{l}\text { 建立与社会主 } \\
\text { 义市场经济相 } \\
\text { 适应、与企业功 } \\
\text { 能定位相配套 } \\
\text { 的市场化劳动 } \\
\text { 用工和收入分 } \\
\text { 配管理体系。 }\end{array}$ & $\begin{array}{l}\text { 管理人员能上 } \\
\text { 能下、员工能 } \\
\text { 进能出、收入 } \\
\text { 能增能减。 }\end{array}$ & $\begin{array}{l}\checkmark \text { 对管理人员, 要完 } \\
\text { 善以岗位职责和 } \\
\text { 任职条件为核心 } \\
\text { 的职级体系, 健全 } \\
\text { 以综合考核评价 } \\
\text { 为基础的选拔任 } \\
\text { 用机制; } \\
\checkmark \text { 探索推行职业经 } \\
\text { 理人制度; } \\
\checkmark \text { 建立健全容错纠 } \\
\text { 错机制。 }\end{array}$ & $\begin{array}{c}\checkmark \text { 建立健全与劳动 } \\
\text { 力市场基本适应、 } \\
\text { 与企业经济效益 } \\
\text { 和劳动生产力挂 } \\
\text { 钩的工资决定和 } \\
\text { 正常增长机制, 优 } \\
\text { 化薪酬结构, 合理 } \\
\text { 拉开收入; } \\
\checkmark \text { 中长期激励政策 } \\
\text { 和工具更加完善。 }\end{array}$ & $\begin{array}{l}\checkmark \text { 加强劳动用工 } \\
\text { 契约化管理; } \\
\checkmark \text { 全面推行公开 } \\
\text { 招聘制度; } \\
\checkmark \text { 畅通员工退出 } \\
\text { 机制。 }\end{array}$ \\
\hline
\end{tabular}




\section{3. 改革趋势研判}

《国企改革三年行动方案 (2020-2022 年)》提出 要坚持和加强党对国有企业的全面领导, 坚持和完善 基本经济制度, 坚持社会主义市场经济改革方向, 抓 重点、补短板、强弱项, 推进国有经济布局优化和结构 调整, 增强国有经济竞争力、创新力、控制力、影响力、 抗风险能力。面对新形势新要求, 国有企业发展活力 仍待进一步提升, 需坚持问题导向、目标导向, 持续创 新、深耕细作:

\section{一是需找准三项制度改革的重点领域、薄弱环节} 和主攻方向, 重点完善岗位竞聘、考核退出、流动配 置、成效共享、改革容错等机制建设, 因企制宜, 持续 推进能上能下、能进能出、能增能减建设。 ${ }^{[4][5]}$ 二是要 统筹协调好三项制度改革与其他改革任务的关系, 有 机衔接, 协同推进, 力争在开展混合所有制改革、“双 百行动” 等改革试点企业中率先取得突破。重点推进 管控模式优化、柔性组织建设、知识资源共享、精准激 励各类人才等工作, 实现人力资本、资金、技术、管理 等生产要素的有机融合, 提升全要素生产率, 释放创 新发展势能。

\section{4. 结论}

国有企业三项制度改革在不同阶段的改革重点在 持续演变, 但其核心要义都在于推进国有企业建立科 学高效的劳动要素配置机制、激励约束机制, 从而提 升国有企业活力、竞争力, 以满足企业与员工发展需 要、适应市场经济发展要求。

在新的历史阶段, 需围绕 “建立与社会主义市场 经济相适应、与企业功能定位相配套的市场化劳动用 工和收入分配管理体系” 要求, 进一步抓重点、补短 板、强弱项, 创新方法、分类施策、系统优化, 推进三 项制度改革取得新成效。

\section{项目基金}

本文为国家电网有限公司科技项目《适应 公司战略的人才供需分析模型及供给策略研究》 的阶段性成果之一。

\section{REFERENCES}

[1] (1992) Questions and Answers on Three System Reforms. J. Reform and opening, 3: 23.

[2] Zhao M. (1993) A Summary of Several Issues in the Three System Reforms. J. Journal of Zhongnan University of Finance and Economics, 05: 77-
$78+104$.

[3] NORINCO, 2017. Policy Interpretation-— How Much Do You Know about the Three System Reforms.

https://www.sohu.com/a/198546950_99964935.

[4] Dong Y. (2015) Thoughts on Deepening the Reform of Three Systems in State-owned Enterprises in the New Era. J. Journal of Petrochemical Management Cadre Institute, 20: 15.

[5] Guo X.Y., Jiao H.K. (2018) Thinking and Innovative Practice of Three System Reform in State-owned Enterprises. J. Economic Research Guide, 10: 11-12+43. 